\title{
Tanulmányok
}

\section{A VÍZTUDOMÁNYOK SZEREPE A FENNTARTHATÓSÁGBAN}

\section{THE ROLE OF WATER SCIENCES IN SUSTAINABILITY}

\author{
Báldi András ${ }^{1}$, Sugár Éva ${ }^{2}$, Bozó László ${ }^{3}$, Engloner Attila ${ }^{4}$, Józsa János ${ }^{5}$, \\ Németh Tamás ${ }^{6}$, Szücs Péter ${ }^{7}$, Vörös Lajos ${ }^{8}$ \\ 1 az MTA doktora, Ökológiai Kutatóközpont, baldi.andras@okologia.mta.hu \\ 2PhD, Magyar Tudományos Akadémia Titkársága \\ 3 az MTA rendes tagja, Országos Meteorológiai Szolgálat \\ ${ }^{4} \mathrm{PhD}$, Ökológiai Kutatóközpont Duna-kutató Intézet \\ 5 az MTA rendes tagja, rektor, Budapesti Múszaki és Gazdaságtudományi Egyetem \\ ${ }^{6}$ az MTA rendes tagja, Kaposvári Egyetem \\ 7 az MTA doktora, dékán, Miskolci Egyetem \\ 8 az MTA doktora, professor emeritus, Ökológiai Kutatóközpont
}

\begin{abstract}
ÖSSZEFOGLALÁS
A földi élet alapja és egyben egyik legnagyobb természeti erőforrásunk a víz, kiemelten az édesvíz. Az ENSZ Fenntartható Fejlődés Célkitűzései között szerepel a fenntartható vízhasználat is, amely a vizek jó állapotát célozza megőrizni a jövő nemzedékei számára. Ezt számos kihívás nehezíti, mind környezeti, mind társadalmi oldalról, például a Kárpát-medencében a melegedés és meleg hőmérsékletekkel kapcsolatos szélsőségek erősödése, illetve a vízgyűjtők határokon átnyúló természete. A fenntartható vízgazdálkodás eléréséhez interdiszciplináris és holisztikus megközelítésre van szükség. Az MTA Nemzeti Víztudományi Kutatási Programjának célja a hazai víztudományok gyakorlati problémáinak megértéséhez és kezeléséhez szükséges tudományos háttér és kutatási evidenciák biztosítása. Ennek érdekében, a víztudományokban újszerűnek számító megközelítést alkalmazva, számos forrásból építkező program született. A program azonosította azokat a tudáshiányokat, ahol tudományos megközelítéssel és modern technikai megoldásokkal fel lehet készülni a szélsőséges helyzetekre, illetve megvalósítható a fenntartható vízgazdálkodás, a vízminőség és a vízi ökoszisztémák megőrzése és javítása. Mindez tudományos alapokat biztosít a Nemzeti Vízstratégia hatékony megvalósításához. Az első ilyen kérdés az ivóvízre fókuszál, és amelynek megválaszolására indult a „Tiszta ivóvíz: a biztonságos ellátás multidiszciplináris értékelése a forrástól a fogyasztókig" című projekt. Ebben a Duna vize és a parti szűrésű kutakból nyert ivóvíz minőségét és az azt befolyásoló tényezőket vizsgálják kutatóintézeti, egyetemi és gyakorlati szereplők. A tudomány és az innováció találkozása az alapvető társadalmi elvárásokkal további kiemelt témákra világít rá: az új típusú szennyező anyagok, például a gyógyszermaradványok és mikroműanyagok; a nagy tavak - kiemelten a Balaton - ökológiai egyensúlya; az öntözés; illetve a fenntarthatóságot támogató "okos" eszközök alkalmazási lehetőségeinek a kutatása.
\end{abstract}




\section{ABSTRACT}

Water, especially fresh water, is the basis of life on Earth and one of our most important natural resources. The United Nations Sustainable Development Goals include the sustainable use of water aiming to maintain good/healthy water conditions for the future generations. The situation is made even more difficult by a number of social and environmental challenges. In the Carpathian Basin these are the overall rise of temperature, the heat extremes, and the transboundary nature of river basins. An interdisciplinary and holistic approach is required to achieve sustainable water management. The purpose of the Hungarian Water Science Programme of the Hungarian Academy of Sciences is to provide the scientific background and research evidence, so a multi-source program has been developed using an approach novel to Hungarian water sciences. The Program identified the knowledge gaps where scientific approaches and modern technical solutions could be used to prepare for extreme situations, to achieve sustainable water management and to preserve and improve water quality, and aquatic ecosystems. The Program also provides the scientific basis for the effective implementation of the National Water Strategy. The first issue focuses on drinking water, and is the subject of the 'Clean Drinking Water: A Multidisciplinary Evaluation of Safe Supply from Source to Consumers' project. In this study, the quality of water in the Danube and drinking water obtained from riverbank filtration wells as well as the factors influencing them are examined by research institutes, universities and practitioners. The meeting of science and innovation with basic societal expectations highlights other key issues for research as novel pollutants, like drug residues and microplastics; the ecological balance of large lakes, especially Lake Balaton; irrigation; and the potential use of smart devices to support sustainability.

Kulcsszavak: ökoszisztéma, mikroműanyag, éghajlatváltozás, öntözés, okoseszközök

Keywords: ecosystems, microplastics, climate change, irrigation, smart devices

\section{BEVEZETÉS}

Víz nélkül elképzelhetetlen az élet a Földön. A következő évtizedekben a víz értéke és jelentősége folyamatosan növekedni fog, a vízhiány pedig olyan komoly konfliktusok kialakulásához vezethet, amely akár háborúkat is kirobbanthat. A víznek kulcsszerep jut az éghajlatváltozást meghatározó folyamatokban is, ezért alapvető fontosságú, hogy nagyobb teret kapjon a nemzetközi együttmüködésekben is.

Az ENSZ tagállamai 2015-ben egyetemes érvényű Fenntartható Fejlődési Célokat fogalmaztak meg. A Fenntartható Fejlődési Célok (Sustainable Development Goals, SDGs) hatodik pontja foglalkozik az édesvízkészletekkel, Tiszta viz és alapvetö köztisztaság címmel, az alábbi főbb területeken: biztonságos ivóvízés szennyvízkezelés, vízminőség, fenntartható vízhasználat, vízgazdálkodás és vízi ökoszisztémák. 
A Duna-vízgyüjtő Európa második legnagyobb vízgyüjtője, területe $801463 \mathrm{~km}^{2}$. Magyarország a Föld egyik legzártabb medencéjében helyezkedik el, ennek a természetföldrajzi vonatkozásnak igen fontos kihatásai vannak a felszíni és felszín alatti vízkészleteinkre. A közel $2800 \mathrm{~km}$ hosszú Duna tíz országon halad át, vízgyüjtő területe pedig további kilenc országot érint. Magyarország teljes területe Romániához hasonlóan egyetlen vízgyüjtő kerületben van.

Hazánk hét országgal szomszédos, amely speciális viszonyokat alakít a felszíni és felszín alatti vízkészletek vonatkozásában. Európán belül itt van fajlagosan a legtöbb határral osztott felszín alatti vízbázis, így az országon kívüli hatások is jelentős mértékben befolyásolhatják felszín alatti vizeink mennyiségét és minőségét, ami sokkal kevésbé közismert, mint az, hogy a felszíni vizeink mintegy 96\%-a nyugati, északi és keleti határainkon keresztül érkezik hazánk földjére. Ezeken a határszéleken Magyarország felszíni és felszín alatti vízkészlete részben kiszolgáltatott alvízi helyzetben van, ahol a környezet- és a klímaváltozás hatásai még intenzívebbek.

\section{ÉGHAJLATVÁLTOZÁS A KÁRPÁT-MEDENCÉBEN}

Európában az éghajlatváltozás lehetséges hatásait tekintve a mediterrán országok mellett a sajátos klímával rendelkező Kárpát-medence az egyik legsérülékenyebb terület. Hazai megfigyelések szerint az utolsó négy évtizedben intenzívebben, csaknem 2 Celsius-fokot emelkedett a nyári középhőmérséklet, illetve nőtt a hőhullámok száma.

A szélsőséges hőmérsékletekben bekövetkezett változásokat jellemző trendértékek arra utalnak, hogy a klíma megváltozása a meleg hőmérsékletekkel kapcsolatos szélsőségek egyértelmü növekedésével és a hideg hőmérséklettel kapcsolatos szélsőségek csökkenésével járt a múlt században.

Az átlagosnál bőségesebb csapadékkal vagy tartós szárazsággal járó események, periódusok előfordulási gyakoriságát az extrémcsapadék-indexek idősoraival és a bekövetkezett változásukkal jellemezzük. Egyre kevesebb csapadékos napot regisztrálunk országos átlagban. A $20 \mathrm{~mm}$-t meghaladó csapadékösszegü napok viszont enyhe növekedést mutatnak, s a száraz időszakok hossza - a leghosszabb időszak, amikor a napi csapadék nem éri el az $1 \mathrm{~mm}$ - $\mathrm{t}$ - pedig jelentősen megnövekedett a 20. század eleje óta. Az átlagos napi csapadékosság nyáron szintén jelentősen megnövekedett, ami arra utal, hogy a csapadék egyre inkább rövidebb ideig tartó, intenzív záporok, zivatarok formájában hullik, ráadásul a területi eloszlás is szélsőségesebbé válik (Lakatos et al., 2016).

Ezek a változások kedvezőtlenül befolyásolják a csapadékvíz talajban, növényzetben történő természetes hasznosíthatóságát. A magasabb átlaghőmérséklet növeli a talaj és a növényzet együttes párolgását, az evapotranszspirációt, tehát a 
talaj-növényrendszerek vízhiánya még a változatlan vagy kevéssé változó éves csapadékösszegek mellett is jelentősen növekedhet, míg a felszín alatti vízkészletek természetes utánpótlódása csökkenhet, kihívásokat jelentve a természetes ökoszisztémáknak és mezőgazdaságnak is.

\section{VIZEINK ÉS A VÍZGAZDÁLKODÁS RÖVID ÁTTEKINTÉSE}

Magyarország vízgazdálkodása jellemzően inhomogén. A külföldről érkező vízfolyások mellett a csapadék mennyisége is jelentős, de a látszólagos vízbőség jellemzően csak a nagy folyók közvetlen környezetében érvényesül (Somlyódi, 2011).

Az Országos Vízgyüjtő-gazdálkodási Terv felülvizsgálata (VGT2) során elvégzett kémiai állapotértékelés a 185 felszín alatti víztest harmadát találta gyenge vagy romló állapotúnak. A felszíni vizek ökológiai minősítése alapján, a vízfolyások mindössze 7, az állóvizek 12\%-a tekinthető jó állapotúnak. A vízfolyások többsége közepes besorolást kapott, jellemzően a biológiai minősítés miatt, kémiai szempontból közel felük megfelel a ,jó állapot” kritériumának. Nagy tavaink (Balaton, Fertő-tó, Velencei-tó) és a szikes tavak ökológiai állapota jó, a holtágak és más módosított víztestek, általában a tápanyagterhelés és a feliszapolódás miatt, nem érik el a jó állapotot.

Míg az ország éghajlati adottságai miatt rendszeresek az aszályos időszakok, addig a Kárpát-medencében az árvízzel fenyegetett területek aránya Európában a legnagyobb. A kedvezőtlen földhasználat és a nem megfelelő mezőgazdasági technológia miatt a termőföldek közel felét rendszeresen belvíz veszélyezteti (OVF, 2017).

A lakossági ivóvízellátás teljes körünek tekinthető. Az ivóvíz minősége döntően kielégíti a közegészségügyi követelményeket. De, föként az alföldi régióban a kutak vize geológiai eredetű veszélyes összetevőket tartalmazhat (As, $\mathrm{B}, \mathrm{F}^{-}, \mathrm{NO}_{2}^{-}$ és $\mathrm{NH}_{4}^{+}$). A szennyvíztisztítás fejlesztésének köszönhetően az elvezetett szennyvizek többsége biológiai tisztítás után a befogadókba kerül, de a kisvízfolyásokba vezetett tisztított szennyvizek még így is rontják a természetes vizek minőségét (OVF, 2017).

\section{AZ MTA NEMZETI VÍZTUDOMÁNYI PROGRAM HÁTTERE}

Az EU Víz Keretirányelv (VKI) célja, hogy a felszíni és felszín alatti vizek, valamint a vizekkel kapcsolatban lévő védett területek ,jó állapotba” kerüljenek, az ehhez szükséges intézkedéseket a vízgyüjtö-gazdálkodási terv (VGT) foglalja öszsze. A jó állapot haszna pénzügyileg is meg lett becsülve, a szabályozó ökoszisz- 
téma-szolgáltatások (vízminőség, élőhelyek, klíma, levegőminőség szabályozása/ fenntartása) értéke több mint egymillió Ft/év/ha-ra tehető (Lengyel et al., 2019).

A már említett SDG-k megvalósítására az európai jogszabályok, szakpolitikai irányelvek is az ENSZ-egyezményhez igazodnak. A VKI legfontosabb célkitüzése a felszíni és felszín alatti vizek jó állapotának megőrzése és javítása, egyúttal a romlás megelőzése, elsősorban ökológiai szempontok szerint. Magyarország első vízgyüjtö-gazdálkodási terve 2010-ben készült el, amelyet hatévenként felülvizsgálnak. A VGT2 2015 biztosítja a VKI célkitüzéseit megvalósító hazai intézkedéseket a mezőgazdaság, az energiatermelés, a hajózás, a turizmus, a vízminőség stb. szakterületeken. A Nemzeti Vízstratégia, a Kvassay Jenő Terv (KJT) Magyarország 2030-ig tartó vízgazdálkodása (38/2012 (III. 12. Korm. r.). Fö célja, hogy a jövő nemzedékek számára megőrizze a vizet mint természeti kincset és stratégiai erőforrást. 2016-ban a KJT tudományos alapjainak biztosítása és a víztudományi kutatások nemzetközi élvonalba emelése végett indult el a Nemzeti Víztudományi Program az MTA koordinálásával. A kormányzati stratégiát is támogató MTA Nemzeti Víztudományi Program keretében először egy elvi koncepció készült a magyar víztudományi kutatások fellendítéséről.

\section{MTA NEMZETI VÍZTUDOMÁNYI PROGRAM}

A Nemzeti Víztudományi Program egyik fő célkitűzése a Nemzeti Víztudományi Kutatási Program elindítása. A kutatási programnak rövid távon hazai feladatokra kell fókuszálnia, ugyanakkor figyelembe kell vennie a vízkincset hosszú távon jelentősen befolyásoló világméretű folyamatokat is. A Nemzeti Viztudományi Kutatási Program kihivásai és feladatai címmel elkészült dokumentum hat fejezete egyben a Fenntartható Fejlődési Célok 6. célterületére reflektáló hat prioritási terület is (Engloner et al., 2019). Az egyes fejezetek felsorolják az adott területhez kapcsolódó legfontosabb kulcsszavakat, tematikailag csoportosítva bemutatják a kutatásokat igénylő problémákat, és a kihívásokból következő kiemelt kutatási feladatokat fogalmaznak meg (URL1).

\section{TISZTA IVÓVÍZ}

Az MTA Nemzeti Víztudományi Kutatási Programja keretében 2018-ban hároméves projekt indult, hogy feltárja Budapest ivóvízbiztonságának veszélyeit. A Nemzeti Kutatási, Fejlesztési és Innovációs Hivatal (NKFIH) Nemzeti Kiválóság Programja által támogatott „Tiszta ivóvíz: a biztonságos ellátás multidiszciplináris értékelése a forrástól a fogyasztókig" címủ projektet az Ökológiai Kutatóközpontból, a Fővárosi Vízművekből, a Nemzeti Népegészségügyi Központból, 
a Budapesti Müszaki és Gazdaságtudományi Egyetemből és a Miskolci Egyetemből álló konzorcium valósítja meg. A főváros ivóvízellátását is biztosító, parti szűrésű rendszerre fókuszáló kutatás vizsgálja a Duna vizét és üledékét, a parti szürésü kutak kezeletlen, majd az elosztóhálózatba jutó, kezelt vizét, továbbá a gerincvezetékben és a fogyasztói hálózatban áramló vizet (1. ábra). Az alapvető fizikai, kémiai és mikrobiológiai méréseken túl megtörténik a vízminőséget meghatározó baktériumközösségek és antibiotikum-rezisztens szervezetek meghatározása, valamint a szerves mikroszennyezők, például a gyógyszermaradványok és bomlástermékeik kimutatása. A projekt céljai között szerepel a vízminőség hosszú távú modellezése különböző klímaváltozási forgatókönyvek alapján; a parti szürés ivóvizet veszélyeztető szervezeteket és vegyületeket eltávolító képességének feltárása, valamint a hálózati vízben kimutatott szennyezők egészségkockázatainak felmérése (URL2).

\section{Mintavétel}

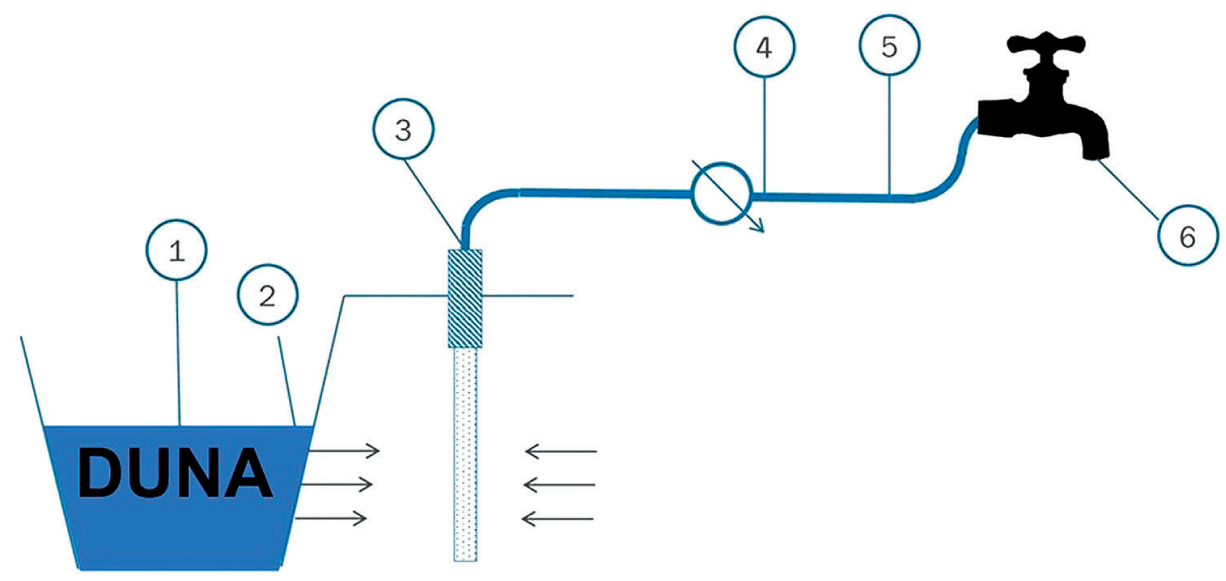

1. ábra. Rendszeres mintavétel a „Tiszta ivóvíz: a biztonságos ellátás multidiszciplináris értékelése a forrástól a fogyasztókig" projekt keretében

1. A Duna sodorvonala, 2. partközeli víztest, 3. parti szürésű kutak, 4. gerincvezeték, 5. elosztóhálózat, 6 . fogyasztó

\section{KIHIIVÁSOK ÉS KITÖRÉSI LEHETŐSÉGEK}

A tudomány és az innováció találkozása az alapvető társadalmi elvárásokkal: az egészséges ivóvíz, a természetközeli vízi ökoszisztémák vagy az egészséges táplálkozás. 


\section{Vízellátás hosszú távú biztositása}

Jelenleg Magyarországon az ivóvízellátás helyzete mennyiségi és minőségi szempontból jó, ugyanakkor több tényező veszélyeztetheti az ellátás biztonságát. A fennálló és új keletủ kihívások között az éghajlatváltozás, az új típusú szennyező anyagok és az elöregedett elosztóhálózatok állapota az elsők között említhetők.

A vízbázisok minőségét a hagyományos szennyező anyagok (például: szervesanyag-, nitrit-/nitrát-, nehézfém- és hőterhelés) mellett korábban nem ismert vagy nem vizsgált, az egészségre potenciálisan veszélyes, ún. új típusú szennyezők is veszélyeztetik. Utóbbiak közül a lakosság számára a gyógyszermaradványok, a szintetikus hormonok, illetve a hormonháztartást károsító vegyi anyagok (EDC) (például biocidok, növényvédő szerek stb.) okozzák a legnagyobb aggodalmat. Az új hatóanyagok nagy volumenủ elöállításának következtében ezek a vegyületcsoportok egyre nagyobb kockázatot jelentenek mind a környezetre, mind az egészségre. Míg a hagyományos szennyezők kármentesítésére már léteznek bevált eljárások, addig az új típusú szennyezők esetében az emberi egészségre és a vízi ökoszisztémákra gyakorolt hatásuk általában nem tisztázott.

A gyógyszermaradványok a felszíni vizekbe elsősorban a szennyvíz közvetítésével kerülnek, mennyiségük csökkentéséhez a szennyvíztisztítás technológiai fejlesztése szükséges. A lehetséges megoldások között oxidáció- vagy membrántechnológia-alapú negyedleges tisztítási eljárások szerepelhetnek. A probléma hosszú távú, hatékony megoldásához azonban az is szükséges, hogy már a kutatás és gyártás során a perzisztencia, bioakkumuláció és az eliminálhatóság szempontjából kedvezőbb vegyületek kerüljenek elötérbe.

\section{A műanyagszennyezés az egyik legnagyobb környezeti problémává vált}

A műanyagszennyezés legfeltünőbben az eldobált italos palackok, csomagolóanyagok formájában jelentkezik, de még nagyobb gondot jelent az, ami nem ilyen feltủnő. A müanyag mechanikai hatások és a Nap ultraibolya sugárzása következtében töredezik, aprózódik egyre kisebb és kisebb részekre, és folyamatosan nagy mennyiségben kerül a környezetbe. Ezek a mikroszkopikus partikulumok az áramló vizekkel és a széllel a világ minden pontjára eljutnak. Részecskeméret alapján megkülönböztethető: mezoplasztik $(5-40 \mathrm{~mm})$, mikroplasztik $(1-5000 \mu \mathrm{m})$ és nanoplasztik $(<1 \mu \mathrm{m})$. A környezetben könnyen és gyorsan mozgó mikro- és nanoplasztik részecskék veszélyt jelentenek a vízi és a szárazföldi élőlényekre is (Peng et al., 2020).

A mikroszkopikus mủanyag részecskék porózus felülete jól adszorbeálja a vízi mikroszennyezőket, többek között a perzisztens szerves molekulákat, antibiotikumokat és akár a mérgező mikróbákat. Másrészt, nagy fajlagos felületük miatt képesek le is adni a káros összetevőik egy részét. A mikroplasztik részecskék 
könnyen bejutnak a vízi táplálékláncba, és képesek felhalmozódni, károsíthatják az állatok emésztőrendszerét, gyulladást okozhatnak, rontják a szaporodóképességet, és gátolhatják különböző enzimek aktivitását.

A különösen veszélyes, nagyon kis méretü nanoplasztik részecskék képesek transzlokálódni az élőlények különböző szövetei és szervei között, károsíthatják a keringési rendszert, a légzőrendszert, az agyat és a máj müködését is. Jelenlétüket többek között kimutatták tengeri gerincesek különböző szerveiből, de az édesvizekben közönséges ezüstkárász agyszövetéből is. Ezek a részecskék az emberre nézve is potenciális veszélyt hordoznak (Mattson et al., 2015). Mintavételük, mennyiségi és minőségi vizsgálatuk csak a legutóbbi időben indult fejlődésnek, ezért kevés információnk van környezeti előfordulásukról.

\section{Magyarország az „ezer tó országa”}

Hazánkban 4600 tó (1 hektárnál nagyobb állóvíz) van, melyeknek 90\%-a mesterséges. A tavak méreteloszlása sajátságos, a nagyon sok pici tó mellett csak néhány nagy kiterjedésű tavunk van, a Balaton pedig egymaga az $596 \mathrm{~km}^{2}$-es területével az összes tófelület 40\%-át teszi ki. A második legnagyobb területủ állóvizünk, az 1978-ban létesült Kiskörei víztározó, harminc évvel ezelött kapott földrajzi nevén Tisza-tó, területe $127 \mathrm{~km}^{2}$, mesterséges, a természet és az ember közös alkotása. Az Ausztriával közös Fertő-tó területe $315 \mathrm{~km}^{2}$, ebből a magyar tórész mindössze $75 \mathrm{~km}^{2}$, és ennek $86 \%$-a náddal borított.

A sok tekintetben kivételes természeti adottságokkal rendelkező Balatont a múlt század hetvenes-nyolcvanas éveiben súlyosan veszélyeztette a lebegő mikroszkopikus algák (döntően cianobaktériumok) tömeges elszaporodása (eutrofizáció), amelynek okozója a vízgyüjtő területről származó és nagyobbrészt a Zala-folyón érkező megnövekedett növényi tápanyagterhelés $(\mathrm{P}, \mathrm{N})$ volt. A külső foszforterhelést csökkentő nagyberuházások (harmadik fokozatú szennyvíztisztítás megvalósítása a vízgyüjtőn, a települési szennyvizet elvezető körcsatorna építése, vízminőségvédelmi tározók létesítése) azonban meghozták a várt eredményt, 1994-től kezdve nem fordult elő kifogásolható mértékü nyári cianobaktérium tömegprodukció a tóban. Így volt ez huszonöt éven keresztül, majd 2019 augusztusában egy fonalas nitrogénkötő cianobaktérium visszahozta a nemzeti kincsnek számító Balaton korábbi, szélsőségesen eutróf (hipertróf) állapotát, és a szezon végére a Keszthelyi-medence vize fürdőzésre alkalmatlanná vált. A Balaton és a Zala-folyó vízminőségének monitorozása évtizedek óta folyamatos, és a rutinmérések nem utaltak vízminőségromlásra, a külső növényi tápelemterhelés megnövekedésére. A tó ismételt algásodása katasztrofális hatással lehet a fejlödő turizmusra, a drága infrastukturális beruházások hasznosulására, és fennáll a jelenség megismétlődésének lehetősége. Egyetlen lehetséges megoldás: az intenzív, multidiszciplináris Balaton-kutatás sürgős újraindítása, a tavi ökoszisztéma 
kulcsfontosságú elemei múködésének részletekbe menő megismerése. Meg kell ismerni a meteorológiai viszonyok, a hőmérséklet, a szél, a felkeveredés hatását a víz-üledék közötti kölcsönhatásokra. Mérni kell az üledékben zajló mikrobiális folyamatok intenzitását a redoxfolyamatok függvényében, a tó vizében lebegő és az üledék felszínén élő egysejtű algák szerepét a tavi anyagforgalomban. A kutatást ki kell terjeszteni a tó vízgyüjtőjére, hiszen a tó állapotát hosszú távon a vízgyüjtő terület történései határozzák meg.

A második legnagyobb állóvizünk, a Tisza-tó alapvető funkciója a vízbázisteremtés, de az öntözővíz iránti mindenkori igény kielégítése mellett prioritást élvező hasznosítási mód az üdülés, az ökoturizmus, és a természetvédelem is. Medrében fokozatosan fejlődött ki egy változatos, az ősi ártéri tiszai tájhoz hasonló környezeti adottságokkal rendelkező páratlanul gazdag élővilág. Nagy kiterjedésủ nyílt vízfelületek, mocsári növényzettel benőtt vizes területek, holtágak, morotvák, vízfolyások, szigetek tarkítják és teszik egyedülállóvá ezt a $127 \mathrm{~km}^{2}$ felületü mesterséges tavat (Laczi, 2018). Ahhoz, hogy ez a rendszer fennmaradhasson, folyamatos müszaki beavatkozásra és vízkormányzásra van szükség, A tó egyes medencéinek eltérő hasznosítása, a fenntartható müködés biztosítása csak a vízi környezet fizikai-kémiai tulajdonságai, a vízi és mocsári növényzet, a lebegő mikroszkopikus algák és a tavat benépesítő állatvilág környezeti igényei közti összefüggések ismeretével lehetséges, de még így sem egyszerủ, tekintettel a folyó esetenként szélsőséges vízjárására. A tó rövid fennállása alatt is megfigyelhetők az egyes évek eltérésein is túlmutató bizonyos nemkívánatos trendek, ezek közül is kiemelendő egyes nyílt vizes területek fokozódó elnövényesedése. A növényborítottság mértéke folyamatosan növekszik, ami valamennyi vízhasznosítási igénynek, beleértve a halállomány életfeltételeit is, kedvezőtlen (Laczi, 2018). Ha azt szeretnénk, hogy a Tisza-tó még hosszú időn keresztül magas színvonalon funkcionáljon, turisztikai vonzereje megmaradjon, intenzív kutatásokat kell kezdeni elsősorban a tó karakterisztikus növényállományainak élete és a fizikai-kémiai környezet kölcsönhatásainak megismerésére, a szükséges beavatkozások megtervezése érdekében.

Harmadik nagy tavunk a Fertő, amelynek Magyarországra eső részén mindössze $10 \mathrm{~km}^{2}$ a nyílt víz területe. A tó az előző két nagy tavunktól eltérően sós sztyepptó, az eurázsiai szikes tavak legnyugatibb tagja, a határon átnyúló Nemzeti Park része. A tó vizének minőségéről több évtizedes adatsorok alapján tudjuk, hogy túlzott mértékủ algásodás nem fenyegeti a tavat. A nádasok kivételesen gazdag madárvilágnak biztosítanak élőhelyet, de a távérzékelési módszerek tanúsága szerint a nehezen vagy szinte egyáltalán nem megközelíthető belső nádas területen a nád pusztul, tarfoltok alakulnak ki. A nyílt víz és a nádasok közötti vízcsere javítása érdekében az elmúlt években kikotort csatornarendszer hatásainak felmérése még most folyik, ennek hatékonyságát hidrológiai és limnológiai 
módszerekkel ellenőrzik. Az egész tóban, de különösképpen a magyar oldalon a nyílt víz és a nádas egyensúlyának hosszú távú fenntartása mindkét ország érdeke, ez a jelenleginél komplexebb és intenzívebb összehangolt hidrológiai, limnológiai és ökofiziológiai kutatásokat igényel.

\section{Élelmezésbiztonság}

A megbízható, kiegyensúlyozott termések eléréséhez a termesztés környezeti hatásainak optimalizálása szükséges. Ennek egyik eleme a megfelelő nedvességtartalom fenntartása talajainkban. Ezt hazánkban a természeti adottságok nem teszik mindig lehetővé. Az évi átlagban lehulló 500-600 mm csapadék egyenlötlen eloszlású. Az ország egyes részein (a Duna-Tisza közén, a Tisza térségében és a Tiszántúlon) a csapadék mennyisége a növények tenyészideje alatt alig éri el a 300-350 mm-t.

A vízhiányos területeken a talaj nedvességének megőrzését elősegítő talajmüvelés (agrotechnika) alkalmazása segíthet. A természetes vízpótlást az öntözés egészítheti ki. A jövedelmet biztosító, gazdaságos öntözésnek a többi, termésmennyiséget befolyásoló tényező optimumhoz közeli állapota szükséges (megfelelő fajta, kielégítő tápanyag-utánpótlás és szakmai felkészültség). Az öntözésre korábban használt területek egynegyedén, egyharmadán használják ezt a lehetőséget a gazdák. Ennek a visszaesésnek az elmúlt harminc évben különböző kiváltó okai voltak (a privatizációt követö birtokrendezetlenségek, elaprózódott birtokszerkezet, az együttműködés hiánya, csatornák és kiszolgáló létesítmények karbantartásának elmaradása, gazdák nem kellő ismerete és felkészültsége, valamint a költségek).

Az utóbbi években az öntözésfejlesztési stratégia kidolgozásakor a felmérések szerint kb. 1,2 millió hektár igényt jelentettek be a gazdák. Kormányhatározat és miniszteri rendelkezések (öntözéses gazdálkodásról szóló törvényjavaslat) is utat nyithatnak az elörelépéshez, melynek szükségességét a jelenlegi időjárási (szélsőségek, anomáliák) körülmények is igazolják. Az öntözés fejlesztése egy átfogó földhasználati stratégia keretében hozzájárulhat az élelmezésbiztonsághoz és a fenntartható mezőgazdálkodás kialakításához.

\section{A FENNTARTHATÓSÁGOT TÁMOGATÓ „OKOS” ESZKÖZÖK ÉS MÓDSZEREK}

Végül szót kell ejteni a szenzorika, adatátvitel és -feldolgozás technológiai hátterének eddig soha nem látott sebességü fejlődéséből adódó jövőbeni lehetőségekről (vö. Hideg et al., 2019) a víztudományok és nem utolsósorban a fenntarthatóság támogatására (URL3). Csupán pár példa: hidrometeorológiai mérőberendezéseink, a tavi, folyami és a felszín alatti vizeink mind rendszeres, 
mind expedíciós megfigyelésére kifejlesztett eszközeink egyre szélesebb körüen, egyre önállóbban, de szükség esetén akár hálózatba szervezve, egymással kommunikálva, a mérési feladatokat az információszerzésre valós időben (real time) optimalizáló megosztásban lesznek képesek elvégezni. Mindezek óriási adattömeget (big data) szolgáltatnak, aminek szinte rögtöni hasznosítását csak villámgyors adatátvitellel (minimum $5 \mathrm{G}$, de már fejlesztés alatt van a $6 \mathrm{G}$ ) és hasonlóan gyors feldolgozással, elemzéssel lehet elérni (archiválásukra „föl velük a felhőbe" [cloud]). Az adatokra épülő, arra arányosított és igazolt, mára már hagyományosnak mondható determinisztikus, strukturált sztochasztikus, fuzzy vagy akár a kaotikus viselkedésü folyamatokat, rendszerviselkedéseket leképző numerikus modellek mellé egyre erőteljesebben fölsorakoznak az elözőekhez hasonló zárt képleteket vagy akár bonyolult differenciálegyenleteket nem használó, a megközelítésben paradigmaváltást hozó gépi tanulási (deep learning) módszerek, immáron mesterséges intelligencia (artificial intelligence, AI) felfogásban bányászva ki az adatokból a bennük lévő információt (data mining), készen az általános hasznosításra. Mindezek nagyon gyors, megbízható állapotértékelését és szabályozását teszik lehetővé vizeink - legátfogóbban mondva - ökológiai állapotának jó tartományban tartásának. Az önmagukban is egyre okosabbra épített szenzorokat pedig víz alatt tájékozódni és közlekedni képes robotúszómúvekre téve, az eddigieknél sokkal összetettebb, „kihegyezettebb" mérési programok hajthatók, hajtathatók végre, nem vagy kevéssé ismert természettudományi összefüggések tárhatók fel, arra további célmérések tervezhetők, mindebből mesterséges intelligencia fegyvertárunk egyre szélesíthető, ténylegesen eljutva egy mindezzel rendszerszinten támogatott akár „okos” Balaton, Fertő vagy Tisza-tó ökoszisztémáig, a tóval szembeni környezeti, társadalmi és gazdasági igények kiegyensúlyozott kielégíthetőségéig.

\section{IRODALOM}

Engloner A. - Vargha M. - Báldi A. - Józsa J. (szerk.) (2019): A Nemzeti Viztudományi Kutatási Program kihívásai és feladatai. Tihany: MTA Ökológiai Kutatóközpont, https://mta.hu/mta hirei/a-nemzeti-viztudomanyi-kutatasi-program-kihivasai-es-feladatai-108691

Hideg É. - Mihók B. - Gáspár J. et al. (2019): Környezeti jövőkutatás - Magyarország 2050. Tihany: MTA Ökológiai Kutatóközpont, https://www.okologia.mta.hu/Kornyezeti-jovokutatas-Magyarorszag-2050

Laczi Z. (szerk.) (2018): Negyvenéves a Tisza-tó. Szolnok: KÖTIVIZIG

Lakatos M. - Bihari Z. - Szentimrey T. (2016): Csapadékszélsőségek alakulása. http://www.met. hu/eghajlat/eghajlatvaltozas/megfigyelt_valtozasok/Magyarorszag/

Lengyel Sz. - Bela Gy. - Zlinszky A. (2019): A biológiai sokféleség és az ökoszisztémaszolgáltatások helyzete Európában és Közép-Ázsiában: az IPBES regionális értékelő tanulmánya. Természetvédelmi Közlemények, 25, 112-130. DOI: 10.20332/tvk-jnatconserv.2019.25.112, https:// bit.ly/3316iAL 
Mattson, K. - Hansson, L-A. - Cedervall, T. (2015): Nano-plastics in the Aquatic Environment. Environmental Science: Processes \& Impacts, 17, 1712-1721. DOI: 10.1016/B978-0-12-8137475.00013-8, https://www.researchgate.net/publication/281514096_Nano-plastics_in_the_aquatic_environment

OVF (2017): Nemzeti Vizstratégia (Kvassay Jenö Terv). Budapest: OVF, https://www.vizugy.hu/ vizstrategia/documents/CE3BFF09-6D1B-4C8F-88B3-CDF70D2AF133/KJT_151120.pdf

Peng, L. - Donghdong, F. - Huaiyuan, Q. (2020): Micro- and Nano-plastics in Marine Environment: Source, Distribution and Threats - A Review. Science of The Total Environment, 698, 134254. DOI: 10.1016/j.scitotenv.2019.134254, https://www.sciencedirect.com/science/article/ pii/S0048969719342378

Somlyódi L. (szerk.) (2011): Magyarország vizgazdálkodása: helyzetkép és stratégiai feladatok. (Köztestületi Stratégiai Programok) Budapest: Magyar Tudományos Akadémia

URL1: https://mta.hu/nemzeti-viztudomanyi-program

URL2: https://tisztaivovizprogram.hu/

URL3: https://iwa-network.org/projects/digital-water-programme) 